\title{
Embedded flexibilization and polite employer domination: the case of short-track apprenticeships in Switzerland
}

\author{
Gina Di Maio ${ }^{1 *}$, Lukas Graf ${ }^{2}$ and Anna Wilson ${ }^{3}$
}

\author{
*Correspondence: \\ gina.dimaio@unisg.ch \\ ${ }^{1}$ Department \\ of Political Science, \\ University of St. Gallen, \\ Müller-Friedberg-Strasse 6/8, \\ 9000 St. Gallen, Switzerland \\ Full list of author information \\ is available at the end of the \\ article
}

\begin{abstract}
Liberalization pressures challenge countries to adapt their training systems. This is particularly relevant for coordinated market economies with firm-driven but collectively governed apprenticeship systems. Recent literature has identified different liberalization trajectories for these countries. For instance, segmentalism describes the increasing influence of large employers in Germany. In Denmark, state agencies manage increased flexibility in training through embedded flexibilization. In this paper, we identify a new form of embedded flexibilization, characterized by polite employer domination. We find this trajectory of liberalization in Switzerland, which represents another training system heavily based on firm involvement. We illustrate our argument with the example of short-track apprenticeship training, which has been expanded in all three mentioned countries in response to ongoing liberalization and deindustrialization pressures. In Switzerland, the relevant reform was initiated by the state while business adopted a rather passive role initially. Yet, state actors eventually stepped back and delegated key competences to employers, which implies that the employers' camp asserted their interests in the end while tolerating some concessions for the benefit of disadvantaged groups. Our process tracing reveals that policy makers used layering to implement short-tracks that enhance social inclusion, while simultaneously increasing the scope of employer cooperation.
\end{abstract}

Keywords: Skill formation systems, VET, Liberalization, Institutional change, Shorttracks, Two-year apprenticeships, Process tracing

\section{Introduction}

National political economies and their skill formation systems face increasing liberalization and deindustrialization pressures, related to factors such as growing global competition, the rise of the service sector, and rapid technological developments (Streeck 2009; Mayer and Solga 2008). The literature on institutional change discusses different reactions to such increasing pressures. While some authors identify a process of policy conversion along the lines of liberalization (Albo 2005; Baccaro and Howell 2011), others highlight the variation in how systems liberalize (Thelen 2012, 2014). For example, Thelen (2012) finds that political economies differ in the extent to which they maintain strategic employer coordination to achieve joint economic gains, on the one hand, 
and equality, on the other hand. It is crucial to understand the effects on equality and employer coordination because both aspects represent central features of political economies and their welfare systems (Estevez-Abe et al. 2001; Martin and Swank 2008).

In order to understand different trajectories of liberalization, studying collective skill formation systems, which are located at the intersection of education and labour market policies, can generate insightful answers. Collective skill formation systems build on the cooperation among state actors, employers, and unions for the purpose of providing vocational education and training (VET) for a broad share of the population (Culpepper and Finegold 1999; Busemeyer and Trampusch 2012; Emmenegger et al. 2019). However, pressures on firms to cost-minimize along with global competition and swift changes in skill demands in the post-industrial era may reduce the number of apprenticeship positions. This risks leaving many young people, specifically those with a weaker profile, without training contracts and, in the longer term, unemployed (Koudahl 2010). Policy actors must therefore pay attention to the fragile balance between broader societal interests and firms' voluntary, but market-driven, willingness to participate as training-providers (Martin and Knudsen 2010; Carstensen and Ibsen 2019; Durazzi and Geyer 2019).

Collective skill formation systems are under pressure to adapt. However, institutional change is "eminently political" (Hall and Thelen 2009, p. 27) and change in collective skill formation systems is influenced by the way the governance of VET incorporates the (often competing) interests of the different stakeholders, which can be linked to specific trajectories of liberalization. Thelen and Busemeyer (2012) show that the German VET system moves from collectivism to segmentalism, due to the increasing influence of large firms at the expense of cross-sectoral interests and collectivist solutions. Such dualization tendencies are argued to most likely occur in countries with sector or industry coordination (Thelen 2012): more specifically where export-oriented manufacturing sectors are dominant in the political economy. Drawing on the Danish VET system, Thelen (2014) identifies a trend towards embedded flexibilization and modularization. In this case, new forms of flexibility enable vulnerable groups to get and keep good jobs (ibid., p. 14). At the same time, these policies are embedded in encompassing frameworks that collectivize social risks such as unemployment or skill shortages. In contrast to Germany, the Danish economy is characterized by a pluralist business community where the manufacturing sectors are not dominant (Ibsen and Thelen 2017). This is seen as a key factor to how Denmark has managed to maintain its high level of solidarity and equality through high-level state capacity. The literature argues that this type of liberalization is typical for Scandinavian, social democratic welfare states (Korpi and Palme 1998; Nelson 2012; Carstensen and Ibsen 2019).

We argue that political economies can also find a way to react to liberalization pressures in which equality is kept on a high level in combination with employer coordination even increasing, for instance, in the form of joint activities through employer associations. In the case of Switzerland, we identify embedded flexibilization that is characterized by what we call 'polite employer domination' (inspired by Pepper Culpepper's seminal work Quiet Politics and Business Power from 2010). We refer to 'polite employer domination' as the strong but not very 'loud' role and influence of employers in policy reform processes which can eventually lead to the delegation of key competences to employers. 
Switzerland-a coordinated market economy (Hall and Soskice 2001), albeit a more liberal variant (Iversen and Stephens 2008; Becker 2009; Mach and Trampusch 2011) -is a core collective skill formation system in which employer coordination through associations and apprenticeship training is even more significant than in Denmark or Germany (Ryan 2012). In particular, the "strong tradition of self-regulation by economic associations" (Mach and Trampusch 2011, p. 15) makes Switzerland an interesting case to study how institutions react and adapt to global competition and liberalization processes. Thus, by adding Switzerland to the debate, we generate general insights into the role of business in collective governance structures.

We illustrate our argument by zooming in on a relatively new policy domain to which the literature on institutional change in VET systems refers, namely the introduction of short-track dual training ('short-tracks') (Thelen and Busemeyer 2012; Thelen 2014). These short-tracks target young people that have difficulties accessing regular-length apprenticeship programmes. We argue that short-tracks make good examples of the mentioned 'fragile balance' between broader social interests (providing access to training for disadvantaged groups) and firms' willingness to provide apprenticeships. Shorttracks entail theory-reduced, applied training and typically last 2 years (in contrast to 3- and 4-year regular training). They build on the same collective skill formation logic as the regular programmes and are an integral part of dual VET, leading to standardized and recognized certificates, but are easier to access and to complete compared to the regular programmes. Three dual VET systems went through reform processes implementing standardized dual short-tracks, namely Denmark, Germany, and Switzerland.

As an empirical case, we concentrate on the VET reform process in Switzerland in the late 1990s and 2000s. This reform introduced standardized short-track training programmes as an additional training path with a distinctive new VET certificate targeting disadvantaged candidates. The highly collective nature of the Swiss VET governance coupled with relatively little state intervention in VET policy (Trampusch 2010; Armingeon 2011; Gonon and Maurer 2012) makes it an interesting case in the family of collective skill formation systems. In as much as Switzerland combines the elements of lesser state influence and highly collectively organized business interest, we see the potential to add key insights to the puzzle of trajectories of liberalization. Therefore, analysing how short-tracks were introduced, our study asks what trajectory of liberalization, if any, the Swiss VET system displays in view of the newly introduced short-track training programmes?

We find that the introduction of short-track training programmes in Switzerland represents a case of embedded flexibilization characterized by 'polite employer domination' The state was the key initiator of the reform and used layering to introduce new training programmes for disadvantaged-before retreating again to allow business to regain control over their implementation in a collective governance set-up. Our research uncovers how the strong position of employers influenced the reform process, even though business did not take a very proactive stance on the issue. This polite domination refers to the passive but salient way in which the employers' camp asserted its interest. Nevertheless, the state was able to enhance access to vocational training for disadvantaged students. Our findings help to better understand the capacity of collective skill formation systems to adapt to liberalization pressures. We present a case that shows that 
embedded flexibilization can also come in a variation in which both social equality and employer coordination maintain high levels - which is an unexpected finding in the view of established trajectories of liberalization. Thus, this is a case where the VET system implements embedded flexibilization but circumvents substantial liberalization.

The following section explains our research design and describes our method and data. The subsequent section analyses the hitherto underexplored Swiss case in detail. In the final section, we interpret and discuss our findings.

\section{Analysing change through trajectories of liberalization}

Our research draws on contemporary literature on the trajectories of liberalization (Thelen and Busemeyer 2012; Thelen 2014; Carstensen and Ibsen 2019). This section introduces three trajectories of liberalization against which our Swiss case can then be discussed. Ultimately we find that embedded flexiblization is the key trajectory in our case, so it is given special attention in this section. Furthermore, we briefly draw on the literature on modes of institutional change in vocational education and training (e.g. Thelen 2004, 2014; Trampusch 2010; Martin 2017) which further sharpens our analytical perspective on the actor constellations as well as the characteristics of the political context.

Thelen $(2012,2014)$ has criticized the prevalent one-dimensional understanding of liberalization as a (declining) degree of coordination. She argues that liberalization can be analytically captured within a two-dimensional field in which strategic employer coordination (' $\mathrm{x}$-axis') and equality (' $\mathrm{y}$-axis') play the central role. In relation to skill formation, Thelen (2014, p. 109ff) refers to three key aspects of training which she uses to characterize institutional change. Firstly, is the access to training narrow (selective) or broad, thus does it support equality or not? Secondly, does the content underline specific or general skills and to which extent do employers cooperate to develop the training content? Thirdly, what (different) paths does the training system offer? Furthermore, the relative power of the organized interest, especially the influence of business actors, shapes the trajectories of change (Thelen 2014, pp. 30-31). Where the manufacturing sector is export-oriented and predominantly composed of large firms, its influence is high and the state is more likely to shape (VET) policies that align with employers' interests (ibid, pp. 30-31). In contrast, where the business camp is diverse, neither dominated by large or small firms nor export-oriented per se and not dominated by the manufacturing sector, employers' influence is lower and the state has more leeway to pursue policies that are more oriented to social solidarity (in the VET policy context). Based on these factors, the literature distinguishes between three ideal typical models of liberalization.

Firstly, 'deregulatory liberalization' is characterized by declining coverage rates and the "active dismantling of coordinating capacities" of the employers (Thelen 2014, p. 13). This trajectory might, for instance, imply that rules and regulations in place to protect collective interests are dismantled in favour of more business- and market-friendly policies (see e.g. Streeck 2009, p. 13). With regard to vocational training, this trajectory translates into low standardization and low levels of cooperation. The state plays a minor role while market players are relatively free to design content and access regulations. Deregulatory liberalization is often considered to take place through institutional displacement. 
The second ideal type is 'dualization' (or 'segmentalism') (Emmenegger et al. 2012; Häusermann and Schwander 2012). It is characterized by a "distinct narrowing in the number of firms and workers covered" by traditional corporatist regulations (Thelen 2014, p. 14). Institutions that facilitate collective action do not disappear, but institutional 'drift' makes them less encompassing because coordination happens more on the sector- and firm-levels-rather than covering the employers and the work force as a whole. For example, some core firms and industries are coordinating and can therefore exert influence over state policies (such as VET), whereas others cannot. Large business players especially strengthen their influence in training and adapt training to their needs and internal labour markets. Furthermore, the state is assumed to be more compliant to pressure from this business interest group, due to its relative economic importance.

Thirdly, there is the 'embedded flexibilization' type of liberalization, which 'involves the introduction of new forms of flexibility within the context of continued strong and encompassing framework that collectivizes risk" (Thelen 2014, p. 14). Training systems are made more flexible by introducing new training paths and training schemes that can be tailored to individual needs. This trajectory of institutional change implies that a high level of solidarity and inclusiveness can be maintained even in the face of the flexibilization of labour market institutions. This is achieved by empowering vulnerable (worker) groups to thrive in a changing labour market while simultaneously maintaining the participation and support of the employers' side. Broad access to training, including disadvantaged groups, plays an important role and is actively supported by the state. However, the encompassingness of employers' cooperation is reduced especially due to state intervention. This is potentially linked to a partial disengagement of employers from apprenticeship training, as their influence in this form of training is reduced (Jørgensen 2015; Carstensen and Ibsen 2019). In contrast to the dualization trajectory, manufacturing interests are typically less pronounced and dominant within organized business (Thelen 2014, p. 31). This leads to a more pluralist balanced power relation between different interests (e.g. manufacturing and service sectors) and opens up space for state agents to strengthen the position of vulnerable groups (Huber and Stephens 2000; Martin and Swank 2012). In their study of institutional change in the Danish VET system, Carstensen and Ibsen (2019) show how the state-under conditions of a leftwing government-is able to broker policy reforms in a coalition with trade unions that may both benefit employers and retain a degree of equality for the disadvantaged.

In instances where trade unions play an important role in the collective skill formation setting, this actor group may be a vehicle for inclusive policy change. In a comparison of VET reforms in Germany and Austria, Durazzi and Geyer (2019) show that while the Austrian unions together with the state were able to promote inclusive vocational training options for disadvantaged candidates, the German unions' opposition to a similar training programme disabled the possibility for such a policy.

We analyse the Swiss VET reform process involving the short-track programmes against the backdrop of these different trajectories of liberalization. Employer coordination and employer domination play a key role in identifying the different trajectories. We understand 'employer coordination' as joint activities between different employers, for example, when employer associations enable the coordination of training content. We understand 'employer domination' as the influence the business camp exercises on 
policy making. In our case study, this influence surfaces in the decision-making process but it is especially the policy-outcome that reflects employer power: employers hold key competences after the reform. We find that the influence of employers is rooted in the state's anticipation of business' gatekeeper role but also the ability of the associations to coordinate, bundle and then voice their common interests. Thus, in our case, employer domination and employer coordination are closely related.

To support our endeavour to discern to which trajectory (if any) the development of short-tracks in Switzerland adheres, we further draw on the theory of gradual institutional change, which complements our toolbox to capture change processes in collective skill formation. More specifically, Streeck and Thelen (2005) describe four specific modes of gradual change: (a) displacement, referring to the introduction of new rules, (b) layering, implying that new rules are added on top of old ones (see also Schickler 2001), (c) drift, linked to a changed impact of a given rule (see also Hacker 2005) and (d) conversion, referring to a new interpretation of a rule. Mahoney and Thelen (2010) argue that layering and drift are more likely to occur than displacement or conversion in a context in which defenders of the status quo hold strong veto possibilities. ${ }^{1}$ However, changes through drift as well as conversion are less likely if the level of discretion in interpreting or enforcing an institution is low. ${ }^{2}$

\section{Methods and data}

Our research relies on secondary literature as well as primary sources. We interviewed ten Swiss VET experts. These experts were selected based on their professional knowledge about short-tracks and to cover all three main actor groups: employers, unions and state actors (see Appendix for the list of interviews). The interviews were semi-structured including open-ended questions. Due to the relatively long time period that has passed since the initial phase of the policy reform process, our expert interviews mostly informed the latter phases of our analysis. In addition, this paper builds on several expert interviews carried out in Denmark and Germany-as our shadow comparative cases (Hancké 2009, pp. 75-77) -within the framework of our previous comparative research on collective skill formation. That is, in some instances we allude to these two cases for illustrative purposes. In addition to the expert interviews, we analysed transcripts from parliamentary VET commission debates, documents of the consultation process between the state, employers and other private stakeholders, as well as other written policy material. To get access to this large corpus of documents (2400 pages in total) through the Swiss national archive, we had to guarantee to treat them confidentially. To the best extent, our two main data sources (i.e. the expert interviews and the document analysis) were used to mutually validate the respective evidence (triangulation by validation, see Peters 1998, p. 97-99). However, interviewees were not confronted with confidential government documents.

Furthermore, we rely on within-case analysis to untangle complicated relationships and causal linkages related to the development of short-tracks. An important method to

\footnotetext{
${ }^{1}$ This is because- unlike layering and drift-conversion and displacement require direct changes to the targeted institution.

2 The reason is that-unlike layering or displacement-both these modes rely on significant leeway in how the institutions are implemented.
} 
identify such causal relations is process tracing, which is guided by the question "what links causal factors, events, sequences and outcomes together" (Trampusch and Palier 2016, p. 442). In other words, which step leads to the next, and what factor(s) ultimately lead to the outcome we observe? This way of doing process tracing is what Collier (2011, p. 823) describes as the "systematic examination of diagnostic evidence selected and analysed in the light of the research question". With the help of process tracing, in the next section we start shedding light on the power relations, the role of the state and the socio-political context surrounding the reforms introducing the 2-year programmes in the Swiss case.

\section{Results: the Swiss case of embedded flexibilization and polite employer domination}

The major Swiss VET reform of 2002 brought flexibilization of training, especially with regard to the length and certification of VET, while strengthening the attractiveness of dual VET for disadvantaged persons and maintaining high levels of employer coordination. The following two subsections elaborate on the trajectory along the lines of embedded flexibilization and the inclusiveness character of short-tracks as well as the related employer influence, respectively. This leads to our argument that short-tracks are a case of employer-dominated embedded flexibilization. The third subsection offers an in-depth process tracing and further establishes that this initially contested change was enabled through layering.

\section{Inclusiveness enhancing short-track apprenticeships: a case of embedded flexibilization}

Dual vocational training is deeply rooted in Switzerland. About two-thirds of graduates from compulsory education (usually at the age of 16) enter dual vocational training (SERI 2017, p. 3). As any collective skill formation system, Swiss VET is based on the voluntary engagement of firms offering training positions. VET governance is highly influenced by business associations. However, the business camp is neither dominated by export-oriented or manufacturing sectors (Gonon and Maurer 2012). In contrast to other educational policy fields in Switzerland (e.g. general education), VET governance is rather centralized and coordinated at the national level (Gonon and Maurer 2012). VET training enjoys a high reputation among students as well as employers (Graf 2013). The share of pupils attending VET is substantive and the finding that, in the case of German-speaking Switzerland, better grades in mathematics actually increase the probability that a student will choose to pursue VET (instead of general education), is a strong indicator for its standing amongst pupils with high educational attainment (Glauser and Becker 2016). However, in the 1990s, the economic downturn led to a retreat of many firms from the apprenticeship system. The number of available apprenticeship positions declined which excluded many candidates from dual VET. Pressures caused by the economic downturn threatened to lead to a further decline in apprenticeship training. As a reaction, in a process initiated by the state, in the late 1990s and early 2000s, the national VET law was revised and entered into force in 2004.

Prior to this reform, there was only one standardized initial VET qualification on the national level. All initial vocational training programmes (berufliche Grundbildung) in Switzerland were certified with a Federal Vocational Diploma (Eidgenössisches 
Fähigkeitszeugnis). Some training programmes, depending on the occupation, took 2 years and others 3 years. However, there was no differentiation along educational levels or certification. Furthermore, the VET law of 1978 had introduced 'pre-training' (Anlehre) targeting "mainly practically talented" candidates (BBG 1978, p. 1127). Yet, the pre-training did not contain a final examination nor a standardized VET certificate.

The reform of 2002 added an additional layer to initial vocational training by introducing a new formal educational level, next to the traditional one. These two levels are distinguished by their different duration and the certification. The new VET law defines that 3- and 4-year training programmes lead to a 'diploma' (Fähigkeitszeugnis) while 2-year training programmes are awarded with a 'certificate' (Attest). The law specifies that the 2-year training programmes should be "adjusted to the specific requirements of the apprentices" (BBG 2002 Art. 17). For the first time, the national VET system offers two different VET certificates that are both standardized and recognized on the national level. In other words, the reform added an additional training track to the system that by law targets disadvantaged candidates. The law even establishes a legal claim for individual support measures for apprentices in 2-year training programmes who are at risk of failing their examinations (BBG 2002 Art.18). These individual support measures include, for example, an adjustment of the training duration, individual counselling sessions in school or case management (Stern and von Dach 2018).

We find that the short-tracks represent a trend towards inclusiveness enhancing flexibilization with the help of layering. Thus far, the State Secretariat for Education, Research and Innovation (SBFI) has conducted three large-scale evaluations (in 2010, 2016 and 2017) that show that the short-tracks are a successful training option for disadvantaged: Since 2004, candidates as well as firms have an additional option to receive and offer vocational training. The access to the traditionally selective vocational training system is broadened as it is made easier for disadvantaged candidates to find and complete an apprenticeship. Additionally, the individual support measures (anchored in the law and applied when needed) also represent increasing flexibility in training provision (on the micro/individual level). These social support measures supplement a standardized core, as training content and certification are standardized.

The individual support measures are organized and financed by the state (the cantons) (Stern and von Dach 2018). In addition, (some of) the cantonal training offices get involved in motivating firms to offer short-track apprenticeships (INT7, INT10). In fact, the cost-benefit ratio on the side of employers offering short-track was shown to be slightly positive on average (Fuhrer and Schweri 2010). In total, short-tracks make up about one tenth of all apprenticeships (SBFI 2016, p. i).

In short-tracks, about one-third of the apprentices come from a bridging measure such as an additional year at school or preparatory courses (SBFI 2016, p. 27). On average, 2-year apprentices are older than their counterparts in 3- or 4-year training programmes are. About half of the apprentices are older than 20 years (ibid., p. 29) and about onethird has a migration background (non-Swiss passport) (ibid., p. 31). The dropout rate (25\%) is higher than in the 3- and 4-year training programmes (ibid., p. 23) but $94 \%$ of those who try, pass the final examination (ibid., p. 23). About $85 \%$ of the graduates enter the labour market or continue training (about $40 \%$ of the graduates enter a 3- or 4-year training) after graduation-in contrast to $94 \%$ of graduates from the longer training 
programmes (ibid., p. 24). The share of short-track apprentices (of all apprentices) varies greatly by region (between 1 and 5\%) (ibid., p. 22). In the French speaking part (Imdorf et al. 2016), the share is much lower compared to the German speaking part. This difference is rooted in lower reputation of VET in this region, in general, but of short-tracks, in particular. In the French speaking part, short-tracks are seen as an emergency solution and local public VET offices check why a candidate signs up 'only' for a short-track instead of a regular programme. Whenever possible, they try to arrange 'regular' training instead of a short-track (INT3, INT4).

Despite the lower acceptance in the French speaking part, and sectoral differences in participation rates (details below), short-tracks successfully became an integral part of the vocational training system. Short-tracks offer an attractive training option for a specific target group. Indeed, the socio-economic characteristics of the apprentices in shorttracks indicate that short-tracks do increase inclusiveness of the traditionally selective VET system. From this point of view, the state was very successful in introducing an inclusiveness enhancing training option. However, we argue that a closer look reveals that it is the employers who are in the driving seat when it comes to the governance and implementation of short tracks.

\section{Employer domination of short-tracks}

Even though the state has a great interest in the successful implementation of shorttracks, these programmes build on the voluntary engagement of employers (for instance, there are no direct public financial subsidies for training firms) and key competencies are in the hands of the employers.

Short-tracks build on the voluntary participation of employers in two ways. Firstly, in Switzerland, so-called 'Organizations of the Working World' (Organisationen der Arbeitswelt), i.e. private multi-actor intermediary associations, are responsible for key governance tasks, such as content definition, and they decide if a short-track apprenticeship programme is developed in their respective occupational field in the first place. These organizations mainly represent occupational and employers' interests and, thus, are driven by the market (INT9). In 2019, the number of short-track apprenticeship programmes reached 60 (compared to 1803 - and 4-year apprenticeship programmes) (SDBB 2019).

However, there is variation in the implementation and demand for short-tracks among different sectors. By far, the highest number of short-tracks can be found in retail (Detailhandelassistent/in EBA). Its share stood at 23\% in 2018 (BFS 2019). Short-tracks in the field of health and social services represent $14 \%$ of all short-tracks, followed by short-tracks in construction (11\%), hospitality and catering (7\%) and metal construction (7\%) (BFS 2019, Tab 2b). In comparison, 20\% of the 3- and 4-year trainings are located in the field of administration and economics, $10 \%$ in retail, $7 \%$ in construction and $6 \%$ in nursing (BFS 2019, Tab 1b).

The outcome of the reform clearly matches the interests of employers. Employers asserted their position in a 'quiet' way. In other words, they did not have to push their position very proactively because policy-makers anticipated employers' power. The arguments brought forward, for example, in the parliamentary debate and discussions in 
the reform committee-"We do not want to make a new VET law that reduces the willingness of companies to train" (WKB meeting March 1, 2001) - reflect that the policy makers strongly anticipated the preferences of business (INT6).

At the same time, the strong employer involvement underlines the collective character of the short-tracks. Collective governance structures are not undermined-instead, short-tracks are embedded into the traditional vocational governance system. However, this dependency on the market can to some extent limit the state's direct influence on the inclusiveness character of the short-tracks.

Against this backdrop, it is interesting to note that the Swiss case of embedded flexibilization is different from the Danish version. While in Denmark, the state weakens some of the collective structures (Jørgensen 2015), the Swiss short-tracks are part of the traditional collective governance structure while at the same time increasing accessibility for disadvantaged students. The Swiss example shows that embedded flexibilization does not have to come with a decline in collective governance and is not restricted to Scandinavian social democratic market economies. However, critics fear that the competitive selection process (firms choosing the candidates) leads to a creaming effect, meaning that the most disadvantaged candidates may not make it into short-tracks (Kammermann et al. 2018; INT5). Thus, it needs to be recognized that Swiss short-tracks might not always reach and include the most disadvantaged candidates.

In sum, we find that the reform in the late 1990s/early 2000s flexibilised the training system in favour of disadvantaged candidates while remaining clearly in the hands of the employers. We next apply process tracing to understand the origins and evolution of short-track training in the Swiss case.

\section{Tracing the policy process}

We identify three critical historical phases in the reform process: (I) the apprenticeship crisis in the 1990s and first policy proposals; (II) the complex multi-actor legislative process by consultation in the late 1990s; and (III) the institutionalization of short-tracks in the early 2000s and the new VET law of 2004.

\section{Phase l: apprenticeship crisis in the 1990s and first policy proposals}

In this section, we show that in Switzerland the flexibilization of VET was driven by state actors who were facing rising youth unemployment in the 1990s. Despite the business camp initially expressing its opposition to use vocational training to integrate disadvantaged students, the Swiss state actors started to develop additional vocational training programmes that would focus on practical training.

In the 1990s, due to economic downturn, the number of applicants exceeded the number of available training positions by far and youth unemployment rose steeply (Theiss 1996; Müller and Schweri 2012, p. 25). This crisis ignited a general societal and political debate on the VET system. Pressured by the Swiss parliament, the Swiss government (Bundesrat) published a report on the 'state of the art' of the Swiss vocational system in 1996 (Bundesrat 1996; CH5). This report stressed that 'practically talented' (praktisch begabte) candidates should not be automatically "guided into school-based training" (Bundesrat 1996, p. 5). Instead, the report suggested to flexibilise apprenticeships, thus to allow adjustments with regard to the duration and requirement levels (ibid., 
p. 9). However, the government did not want to change the legal basis but suggested minor adjustments such as the development of a tool to assess supply and demand on the apprenticeship market or to increase its support for the cantons to integrate foreign youth into the labour market. It offered to use a 10 Mio CHF budget (ibid., p. 14).

However, the parliament and the unions harshly criticized the suggested measurements for not tackling the structural problems in VET (Strahm 2008; Polito 2014). The political debate intensified and the Science, Education and Culture Committee of the parliament (Kommissionen für Wissenschaft, Bildung und Kultur (SECC)) played a central role in it. For this commission, the questions about how to increase the number of apprenticeship positions in firms and how to integrate more (disadvantaged) candidates into dual VET were the driving force (see the SECC mandate "incentive scheme" from January 10, 1997). As the situation on the apprenticeship market did not improve and political pressure grew, the government launched two immediate support packages (Lehrstellenbeschluss I and II) in 1997 and 1999 worth 160 Mio CHF (WBK 1999). The first package focused on measures and projects to increase the number of apprenticeship positions, for example, through stronger engagement of the cantonal VET offices or subsidies for advertisement campaigns. Furthermore, the first package supported pilot projects that developed training opportunities for those with difficulties to find an apprenticeship training. These included, for example, bridging educational offers such as an additional year at school and preparatory courses. It is the second package that specifically proposes to develop "new occupations" that "require mainly applied tasks" to create new training options (Bundesversammlung 1999, p. 2).

Before the second package was granted, it was important to the parliament to hear the opinion of employers. For this purpose, Herrmann (1997) conducted a survey among employers, commissioned by the parliament. This effort underlines the importance of the preferences of employers to the policy makers. The results of the survey showed that employers were very reluctant to open more vocational training for disadvantaged students. They emphasized that apprenticeship training should not be a means to integrate weaker students. Rising skill demands would not allow them to accept weak candidates (Herrmann 1997).

The employers made clear that they consider solely the state to be responsible for supporting disadvantaged students, for example, through state-funded preparatory courses (Herrmann 1997). However, even though the business camp expressed its opposition to facilitate access for disadvantaged persons to VET, the second support package granted 40 Mio CHF to explore occupational training fields with "mainly applied tasks" (Bundesversammlung 1999, p. 3). In the parliament, the package received "wide support" from all parties without discussions on the content (Schlumpf 1999). However, the support package did not include any binding regulations, which essentially left the employers' autonomy with regards to training provision for the disadvantaged intact. Instead, the package offered funding for pilot projects that would test and evaluate new training approaches.

The development and preparation of the support packages (and later the new VET law) was mainly driven forward by public actors, namely the Science, Education and Culture Committee of the parliament and the parliament itself (INT8). However, it has to be pointed out that this committee regularly invited representatives from 
various stakeholders including unions, the trade sector (Gewerbe) and representatives from the VET teachers (Berufsbildung Schweiz) (minutes SECC meeting January $14 / 15,2002$, INT8). With regard to the idea to introduce short-tracks, however, there was very little pro-active involvement of business actors in this phase (INT7, INT9). Business was not very 'loud' in the policy process around the establishment of the short-tracks. Rather, the state-which in the Swiss case has been found to be strongly interested in a well-functioning and stable training system (Seitzl and Emmenegger 2019, p. 153) - was under pressure to react to declining numbers of apprenticeship positions and a growing number of unemployed youths.

Finally, in 1998, the government appointed an expert group to start the revision process of the VET law. Even though the support packages technically were mainly financial means, the second package especially functioned as a key point of orientation for the revision (Strahm 2008). Representatives of the trade association (Gewerbeverband), unions, employer associations and politicians were members of the expert group (Strahm 2008). The new VET law proposal and an explanatory report were presented in May 1999. The expert group report addresses the need to create more training opportunities for those facing difficulties entering dual training-an agreement that indicates the common understanding among policy makers as well as union and employer representatives of the seriousness of the issue of entry barriers to training for disadvantaged youth. The group's report refers to the negative image of the pre-training ('second-order' training) and argues that the pre-training was not able to reach enough candidates in need (EVD 1999, p. 11). Furthermore, the expert group report highlights that growing differentiation in the world of employment requires "more flexible" levels of qualification (EVD 1999, p. 12, 22).

The report also suggested that the law defines the duration of a regular apprenticeship to take at least 3 years (EVD 1999, p. 22). Additionally, the VET law proposal should introduce 'applied vocational training' (berufspraktische Bildung) (EVD 1999, pp. 26-27), a training opportunity that can be adjusted to "individual competences" but that can also be used to establish demanding training programmes that take less than 3 years. Applied vocational training focuses on work-based training (EVD 1999, p. 36) and apprentices with learning difficulties should be supported by individual support measures (EVD 1999, p. 27). This new training level would be linked to a new VET degree. The policy proposal suggested granting graduates from the applied vocational training usually a 2-year 'federal VET certificate' (Berufsattest), while the regular 'federal VET diploma' (Fähigkeitszeugnis) would last 3 or 4 years (EVD 1999, p. 36).

Overall, these statements reflect the strong interest of the state to strengthen the social dimension of vocational training. However, it is also important to note that the state refers to the changing demands on the labour market as the primary driving forces for change. It argues that training has to adapt to the changes that "the labour market dictates" (EVD 1999, p. 11). The needs of the disadvantaged students come second (see EVD 1999, p. 22), which underscores the considerations and standpoint of the employers with regards to the 2-year programmes. The policy proposal by the expert group, thus, reflects a compromise of two camps. On the one hand, the proposal introduces a new training option to enhance the integration of disadvantaged 
candidates. On the other hand, the proposal highlights that economic demand is the driving force for the introduction of new training tracks. The proposal strengthens the traditional apprenticeships but introduces an additional option for disadvantaged students.

\section{Phase Il: the complex multi-actor legislative process by consultation in the late 1990s}

The new VET law proposal was on the table by 1999 and suggested the introduction of an additional VET level and certification. In this section, we argue that the reactions by key players to this proposal can be divided into three main lines of argument. Firstly, the cantons and the unions welcomed short-tracks as a social measure to increase inclusiveness of VET. Secondly, occupational and employer associations were not in favour of the idea of lower level training because they saw the danger of devaluation of traditional VET and additional costs due to more intense supervision of short-track apprentices. These two insights demarcate a clear difference to the German case, where the employers' camp was the key driver of short-track training. Thirdly, these same associations demanded more influence with regard to programme development and content definition.

The compromise reflected in the new VET law proposal are, in part, the result of the negotiation process within the expert group that partly brought together the interests of the state, business and the unions. Nevertheless, the different positions of these actor groups become very clear in the reactions to the policy proposal. In Switzerland, policies of high relevance undergo a legislative process by consultation (Vernehmlassung). In this process, the state invites cantons, parties, umbrella associations representing employers, occupational and employee's interests and other interested actors to comment on policy proposals before they enter the parliamentary debate (Bundesrat 2017). In May 1999, the federal economic department opened the consultation on the new VET law proposal. The department received 218 answers (EVD 2000). Our analysis of the responses, presented below, illustrates the above mentioned three main lines of arguments. ${ }^{3}$

Short-tracks as a social measure On the one hand, we observe strong support for applied vocational training as a means to include disadvantaged candidates into the training system. The cantons particularly highlighted the social role of the applied vocational training. For the cantons, it was of high importance to guarantee permeability from the applied vocational training to further training options such as other levels vocational training (e.g. cantons Schaffhausen, Luzern, Zurich, Basel-Landschaft). In addition, the provision of support measures to prevent discrimination was very relevant (e.g. canton Nidwalden).

Unions took a similar stance. Initially, they had opposed the introduction of a new and lower training level as they had been afraid of a downgrading of VET (INT1, INT3, INT4). Instead, they had suggested that short-tracks prepare candidates for a regular

\footnotetext{
${ }^{3}$ This section is based on the statements of the actors in the consultation process. However, these statements are not public. Only an anonymized summary of the consultation results was published by the EDV in 2000. The authors of this paper received access to the individual responses through the federal Swiss archive in Bern under the condition not to publish the documents. Thus, we chose to refer to the actors but do not make their statements explicit in the reference list.
} 
training programme (INT4) and emphasised (and still do) that 3- and 4-year training should be the norm (INT3). However, after intense discussions within the union camp (INT3) their opposition weakened when the possibility of individual support measures was added (INT4). This changed the union's view on short-tracks, which unions now saw as an opportunity to increase the number of youth in apprenticeships, especially those lacking academic credentials (INT3). This position was taken up by the expert group that developed the policy proposal. Beyond this, the unions also strongly demanded to guarantee the permeability from short-tracks into further training. At the same time, the Swiss Union Confederation (SGB) as well as the Christian National Union Confederation pointed out that occupational associations should be responsible for the development of applied training but also wanted more binding rules for the participation of business in training.

Interestingly, some cantons feared that the new standardization would not allow the training to adjust to the individual needs of the apprentice (e.g. cantons Graubünden, Uri, Zug). Also, some cantons argued that short-tracks would be a 'second class' training, discriminating graduates and excluding the graduates from further training options (e.g. the cantons Uri, Obwalden). Even though the cantons very much underlined the social aspect of an additional VET level, some cantons also expressed their fear that additional costs would keep firms from participating (e.g. canton Schaffhausen). This reflects the anticipation of business interests by the cantons.

Short-tracks as a devaluation of traditional VET The second line of argumentation views the introduction of a lower VET level as a devaluation of training and thus, rejects this idea (INT2). This argument was often brought forward by employer and occupational associations (e.g. Association of the Master Butchers, Swiss Textiles Association). In particular, those occupational fields that already had regular 2-year training programmes not specifically targeting disadvantaged candidates (such as the retail or dairy business) were afraid of a downgrading their training programmes (e.g. Swiss Association of Household Arts). One of the main arguments against applied vocational training was the fear of additional costs that would come with more intense supervision of weaker candidates. In the 1990s, the employers were in the convenient position to handpick apprentices as more applicants were on the market than training places. From this perspective, there was no need for employers to demand an additional training level.

At the same time, some associations (especially occupational associations) argued that training for disadvantaged should not be limited to 2 years but instead more time should be allowed for slower learners to acquire the skills to suffice the occupational demands (e.g. Association of Swiss Printing Industry, Association of ICT Training). This reflects a measure of compassion for the disadvantaged youth on behalf of the employers, but also an understanding of the seriousness of the problem and the role of business as part of the solution.

Short-tracks and the role of the Organizations of the Working World Another line of argument centred on the involvement of the Organizations of the Working World. Initially, the state's proposition delegated the development of short-tracks to the cantons. This would imply a loss of influence for the employers and occupational associations that 
traditionally develop the training content in VET. Therefore, the employers and occupational associations demanded to regulate short-tracks on the national level and to anchor their responsibilities for short-tracks in the law, like in the case of regular apprenticeships (e.g. Viscom, Association of Farmwomen, Swiss Insurance Association). They argued that cantonal variation of short-tracks would reduce their reputation. Some associations expressed that the law should mention the needs of the training firm next to mentioning the needs of the apprentice (e.g. Gastro Suisse, Association of Agronomist). Others underlined that graduates from applied vocational training should not be considered to be part of the occupational field but that a clear distinction, especially with regard to the certificate between the two levels of training and graduates, was needed (e.g. Association of the Automotive Sector). In this context, it is also important to note that we do not observe a significant divide of preferences along firm size-which speaks against the presence of significant segmentalist trends in the Swiss case.

After the consultation process, the policy proposal was slightly revised along the lines of the employers' camp's wishes. One year after the consultation process, the government published an explanatory report on the new policy proposal. In the next section, we focus on the specific institutionalization of short-tracks in the VET law of 2004 that builds on the consultation process and actors' respective positions.

\section{Phase III: institutionalization in the early 2000s and the VET law of 2004}

In this phase, even though large parts of the business camp were initially sceptical about an additional layer in VET, the new VET law introduced an additional VET track by specifying that 2-year trainings are rewarded with a new VET certificate.

As a result of the legislative process by consultation, in 2000 the government published its "message on the new VET law" (Bundesrat 2000) and in 2002 the two chambers of the parliament passed the bill. In 2004, the new VET law entered into force. The original policy proposal had been revised after the consultation process. For example, the term 'applied vocational training' ('berufspraktische Bildung') disappeared. Yet, with the new short-track training, an additional training option for disadvantaged formally entered the law without directly altering the existing character of the 3- and 4-year programmes - a form of 'layering' (see theory section).

The law defined that initial vocational training can take "two to four years" (BBG 2002). The additional training option then entered through the specification of the certification in relation to the duration of training. The law specifies that 3- and 4-year training programmes are awarded with a 'Federal VET diploma' (Eidgenössisches Fähigkeitszeugnis) while the 2-year training programmes led to a 'Federal VET certificate' (Eidgenössisches Berufsattest). Additionally, the law grants individual assistance and support measures to those apprentices who might otherwise fail their training.

From the legal perspective, this design of the short-tracks underlines the social dimension of training. It was important for the unions and the cantons to create a training option for disadvantaged candidates. However, the unions had to surrender on their demand to include binding regulations for employers and a training guarantee.

With the short-tracks, the state received a new means to integrate disadvantaged students into dual vocational training. Short-tracks are a cheaper option than school-based 
bridging classes. At the same time, the government found a way to keep businesses on board by not including binding regulations and by not changing the 'core' of VET, the 3and 4-year training programmes, but instead to 'layer' the 2-year programmes onto the existing system. The business side, not least due to its rather united position on the policy in question, eventually gained control over the implementation of the short-tracks.

However, even though the design of the short-tracks did integrate the interests of business, the state actors were worried whether the short-tracks would fall on fertile soil and take off (INT7, INT10). This is one of the main reasons why the state invests in continuous close monitoring of the development of short-tracks. At the same time, the risk that the state pushes equality-enhancing measures too far, thus disengaging business, is limited as it faces a business camp that is relatively coherent in its position that it should play a pivotal role in apprenticeship training, whether in the regular or the short-track version.

\section{Discussion and conclusion}

Globalization and liberalization pressure the institutional configuration of political economies with collective governance structures. Thelen $(2012,2014)$ argues that liberalization takes place in a two-dimensional space composed of equality and strategic employer coordination. In our study, we show that the Swiss trajectory is ultimately not connected to a decline of equality or strategic employer coordination. The new training programmes increase equality by making it easier for disadvantaged to enter the system and to complete a certified training. At the same time, employer cooperation expands because they collectively govern the new training programmes.

In the face of the apprenticeship crisis of 1990s, employers were not willing and could not be forced to train more apprentices, especially with regard to weaker students. Thus, regular training programmes could not solve the crisis. A conversion or displacement of regular training programmes was not possible due to the strong influence of the business camp in the Swiss VET system. In addition, large-scale institutional drift did not take place due to the strong institutionalization of regular apprenticeships in Switzerland. In this political context, the most feasible choice for the state actors in the frame of dual VET was layering. This refers to the introduction of short-tracks as an additional new training level, through creating the voluntary option for employers to participate and investing in social support measures. Nevertheless, it was a risky decision to add a new training level and not everyone believed that it would work (INT10). Yet, our empirical findings suggest that layering in the form of short-tracks does-at least until now-not fundamentally undermine the traditional core of the apprenticeship training but rather serves to accommodate pressures for institutional change related to a changing environment and liberalization pressures.

Given that Switzerland is considered to be the most liberal collective skill formation system (Emmenegger et al. 2019), both the state's capacity and the influence of the unions proved stronger than expected. Under pressure to bring more young people into dual vocational training, the state initiated the introduction of short-tracks and a corresponding collective governance infrastructure, although both unions and employers initially opposed a lower level within VET. They were afraid of a devaluation of vocational training as well as additional costs that might be attached to more intense one-to-one supervision 
of apprentices in the firm. This is one of the most important differences to the dualization trajectory in the German case where the demand for flexibilization is mainly driven by the employers' camp, primarily dominated by large firms in the manufacturing sectors (Thelen and Busemeyer 2012). Furthermore, the position of the Swiss unions also differs from that shown in other countries where unions instead have marshalled inclusive measures in opposition to the employers (see Durazzi and Geyer 2019; Carstensen and Ibsen 2019). Likewise, the Swiss employers were initially sceptical of more flexible training.

For the state's initiation of short tracks, the composition of the employer's camp played an important part. Switzerland is not dominated by a strong manufacturing nor exportoriented sector per se but a rather pluralistic group of business actors (Gonon and Maurer 2012; Mach and Trampusch 2011). However, we found that business was able to speak with a relatively coherent voice when it came to short-track training. Traditionally, business in Switzerland is well coordinated and organized in sectoral and occupational associations which can bundle the interests of their members (Trampusch 2010). These associations are key players in the governance of vocational training and influential, for instance, as they decide on the introduction of training programmes and define the content of training. The related high level of employer coordination in combination with their gatekeeper position enabled business to exercise power over the reform process around short-tracks. Employers were aware of their strong position from the very start, which is why they could afford to stay rather passive during the reform process.

The state took the preferences of business very seriously and delegated key competences in the governance of short-tracks to the employers. For instance, employer and occupational associations decide autonomously if they want to introduce a shorttrack training programme in their respective sector or occupational field. In sum, the Swiss short-tracks can be described as politely employer-dominated, meaning that the employers' camp asserted their interests in the end despite their rather passive role in the reform process.

Furthermore, the state did also listen to the unions and to get their support, the new VET law includes the possibility of state-funded individual social support measures. At the same time, the employers tolerated some concessions to the benefit of disadvantaged groups by accepting the need for (potentially) more intense supervision on a case-bycase basis as well as a re-organization of pre-existing 2-year programmes related to new national level training certificates and standards.

The influential role of business distinguishes the Swiss from the Danish type of embedded flexibilization. In Denmark, the strong aim to adapt the training to the most disadvantaged youth dictated the configuration of short-tracks rather than the perspective of employers. In Switzerland, even if business was not very 'loud', its influence on the design of short-tracks eventually was very strong. Their rather passive stance during the initial phase of the reform most likely reflects an assuredness within the business camp that the state would ultimately not coerce them into an arrangement they would strongly disagree with.

Furthermore, we did not find a strong left-right divide in the parliamentary debate, related to the deeply-rooted idea on both ends of the political spectrum that successful VET needs to be steered by the needs of the labour market actors. The 'strategic employer coordination' capacities of organized interest were therefore not 
threatened by state intervention, as identified by Thelen (2014) and Carstensen and Ibsen (2019) for the Danish case. In the Swiss case, employer cooperation (reflected in the important role of employers' associations) remained dominant due to the retreat of the state from the policy issue once the initial reform steps were taken. Thus, the Swiss short-track reform is indicative of a new variant of embedded flexibilization linked to a continued high level of equality and a maintained high level of strategic employer coordination.

Our findings contribute to the understanding of institutional change in the Swiss skill formation system. Trampusch (2010) has described change in the Swiss VET system as self-preserving and transformative. We add to this that the Swiss VET reform made the training system more flexible and accessible for disadvantaged persons while maintaining a high level of employer coordination. In contrast to previous research on the fate of collective systems in the post-industrial era, this finding is a rather optimistic testimony to the promises of a collectively governed training system that at the same time manages to provide options for weaker learners but without deterring involvement of firms even in a challenging economic environment.

In this context, we also contribute to the literature on liberalization trajectories that has mainly referred to countries with a strong social democratic history (such as the Scandinavian countries) to be the typical cases of embedded flexibilization. We broaden this view by adding the Swiss case to the family of cases of embedded flexibilization-but suggest that it is of a more employer-dominated type than in Scandinavia. Further research can build on these findings to measure the individual social mobility patterns associated with each of these institutional configurations around short-track training.

The insights that our study generates can also inform future policy-making that aims at enhancing inclusiveness. Crucially, the combination of layering with continued voluntary engagement of employers seems to be a promising strategy to introduce inclusion-enhancing measures. However, delegating key competences to business and thus having employers as gatekeepers has some limiting effects on inclusiveness. Therefore, in collective skill formation, as elsewhere, finding a balance between economic efficiency and social equality remains a complex policy challenge.

Acknowledgements

We are very grateful to the members and the scientific advisory board of the Swiss research cluster entitled Governance in Vocational and Professional Education and Training (GOVPET) for their generous and insightful comments.

\section{Authors' contributions}

All authors read and approved the final manuscript.

\section{Funding}

This work was supported by the Swiss research cluster entitled Governance in Vocational and Professional Education and Training (GOVPET), a Leading House project financed by the State Secretariat for Education, Research and Innovation (SERI).

Availability of data and materials

The policy documents analysed during the current study cannot be shared publicly by the authors for reasons of confidentiality but are accessible in the Swiss National Archive.

\section{Competing interests}

The authors declare that they have no competing interest.

\section{Author details}

${ }^{1}$ Department of Political Science, University of St. Gallen, Müller-Friedberg-Strasse 6/8, 9000 St. Gallen, Switzerland. ${ }^{2}$ Hertie School of Governance, Friedrichstraße 180, 10117 Berlin, Germany. ${ }^{3}$ Swiss Graduate School of Public Administration Quartier UNIL-Mouline, Bâtiment IDHEAP, University of Lausanne, 1022 Lausanne, Switzerland. 


\section{Appendix}

See Table 1.

Table 1 Overview interviews

\begin{tabular}{llll}
\hline Code & Actor type & Date & Location \\
\hline INT1 & Trade union & 13-Dec-2016 & Bern \\
INT2 & National state actor & 15-Mar-2017 & Bern \\
INT3 & Trade union & 16-Mar-2017 & Bern \\
INT4 & Trade union & 24-Sep-2017 & Bern (written email statement) \\
INT5 & National research institute & 04-Oct-2017 & Zollikofen \\
INT6 & Regional state actors organised on the national level & 04-Oct-2017 & Bern \\
INT7 & National state actor & 23-Oct-2017 & Bern \\
INT8 & National state actor & 26-Oct-2017 & Münsingen (telephone interview) \\
INT9 & National employer association & 24-Nov-2017 & Zurich \\
INT10 & Regional state actors organised on the national level & 11-Sep-2018 & Bern \\
\hline
\end{tabular}

Received: 22 September 2019 Accepted: 19 March 2020

Published online: 30 March 2020

\section{References}

Albo G (2005) Contesting the 'new capitalism'. In: Coates D (ed) Varieties of capitalism, varieties of approaches. Palgrave Macmillan, Basingstoke, pp 63-82

Armingeon K (2011) A prematurely announced death? In: Trampusch C, Mach A (eds) Switzerland in Europe. Routledge, London, pp 165-185

Baccaro L, Howell C (2011) A common neoliberal trajectory. Polit Soc 39:521-563

BBG (1978) Bundesgesetz über die Berufsbildung. Bundesversammlung der Schweizerischen Eidgenossenschaft, Bern

BBG (2002) Berufsbildungsgesetz (BBG). Bundesversammlung der Schweizerischen Eidgenossenschaft, Bern Becker U (2009) Open varieties of capitalism. Palgrave Macmillan, Houndsmill

BFS (2018) Berufliche Grundbildung - Lehrverhältnisse. https://www.bfs.admin.ch/bfs/de/home/statistiken/bildung-wisse nschaft/personen-ausbildung/sekundarstufe-II/berufliche-grundbildung-lehrverhaeltnisse.html. Accessed 2 Apr 2019

BFS (2019) Berufliche Grundbildung: Basistabellen. https://www.bfs.admin.ch/bfs/de/home/statistiken/bildung-wissenscha ft/bildungsabschluesse/sekundarstufe-Il/berufliche-grundbildung.assetdetail.8186155.html. Accessed 28 Nov 2019

Bundesrat (1996) Bericht über die Berufsbildung. Schweizerische Eidgenossenschaft, Bern

Bundesrat (2017) Vernehmlassung. https://www.admin.ch/gov/de/start/bundesrecht/vernehmlassungen.html. Accessed 3 Nov 2018

Bundesrat (2000) Botschaft zu einem neuen Bundesgesetz über die Berufsbildung (Berufsbildungsgesetz, BBG). Schweizerische Eidgenossenschaft, Bern

Bundesversammlung (1999) Bundesbeschluss über Massnahmen zur Verbesserung des Lehrstellenangebotes und zur Entwicklung der Berufsbildung (Lehrstellenbeschluss II). Bundesversammlung der Schweizerischen Eidgenossenschaft, Bern

Busemeyer MR, Trampusch C (eds) (2012) The political economy of collective skill formation. Oxford University Press, Oxford

Carstensen MB, Ibsen CL (2019) Three dimensions of institutional contention. Socio-Econ Rev. https://doi.org/10.1093/ ser/mwz012

Collier D (2011) Understanding process tracing. Polit Sci Polit 44:823-830

Culpepper PD (2010) Quiet politics and business power. Cambridge University Press, Cambridge

Culpepper PD, Finegold D (eds) (1999) The German skills machine. Berghahn Books, New York

Durazzi N, Geyer L (2019) Social inclusion in the knowledge economy. Socio-Econ Rev. https://doi.org/10.1093/soceco/ mwZ010

Emmenegger P, Häusermann S, Palier B, Seeleib-Kaiser M (eds) (2012) The age of dualization. Oxford University Press, Oxford

Emmenegger P, Graf L, Trampusch C (2019) The governance of decentralised cooperation in collective training systems. J Vocat Educ Train 71:21-45

Estevez-Abe M, Iversen T, Soskice D (2001) Social protection and the formation of skills. In: Hall PA, Soskice D (eds) Varieties of capitalism. Oxford University Press, Oxford, pp 145-183 
EVD (1999) Revision des Berufsbildungsgesetzes Erläuternder Bericht für die Vernehmlassung. Eidgenössisches Volkswirtschaftsdepartement, Bern

EVD (2000) Bundesgesetz über die Berufsbildung Ergebnis der Vernehmlassung. Eidgenössisches Volkswirtschaftsdepartement, Bern

Fuhrer M, Schweri J (2010) Two-year apprenticeships for young people with learning difficulties: a cost-benefit analysis for training firms. Empir Res Vocat Educ Train 2:107-125

Glauser D, Becker R (2016) VET or general education? Effects of regional opportunity structures on educational attainment in German-speaking Switzerland. Empir Res Vocat Educ Train. https://doi.org/10.1186/s40461-016-0033-0

Graf L (2013) The Hybridization of Vocational Training and Higher Education in Austria, Germany, and Switzerland. Budrich UniPress, Opladen

Gonon P, Maurer M (2012) Educational policy actors as stakeholders in the development of the collective skill system. In: Busemeyer MR, Trampusch C (eds) The political economy of collective skill formation. Oxford University Press, Oxford, pp 126-149

Hacker J (2005) Policy drift. In: StreeckW, Thelen K (eds) Beyond continuity. Oxford University Press, Oxford, pp 40-82

Hall PA, Soskice D (eds) (2001) Varieties of capitalism. Oxford University Press, New York

Hall PA, Thelen K (2009) Institutional change in varieties of capitalism. Socio-Econ Rev 7:7-34

Hancké B (2009) Intelligent research design. Oxford University Press, Oxford

Häusermann S, Schwander H (2012) Varieties of dualization? In: Emmenegger P, Häusermann S, Palier B, Seeleib-Kaiser M (eds) The age of dualization. Oxford University Press, Oxford, pp 27-51

Herrmann V (1997) Lenkungsmassnahmen für den Lehrstellenmarkt. GfS-Forschungsinstitut, Zürich

Huber E, Stephens JD (2000) Partisan governance, women's employment, and the social democratic service state. Am Sociol Rev 65:323-342

Ibsen CL, Thelen K (2017) Diverging solidarity. World Polit 69:409-447

Imdorf C, Berner E, Gonon P (2016) Duale versus vollzeitschulische Berufsausbildung in der Schweiz. In: Leemann RJ, Imdorf C, Powell JW, Sertl M (eds) Die Organisation von Bildung. Beltz, Weinheim, pp 186-207

Iversen T, Stephens J (2008) Partisan politics, the welfare state, and three worlds of human capital formation. Comp Polit Stud 41:600-637

Jørgensen CH (2015) Recent innovations in VET in Denmark. Department of Psychology \& Educational Studies, Roskilde University, Roskilde

Kammermann M, Balzer L, Hättich A (2018) Arbeitsmarktintegration und Berufsverläufe von Personen mit einem Eidgenössischen Berufsattest. In: Becker M, Kammermann M, Spöttl G, Balzer L (eds) Ausbildung zum Beruf. Peter Lang GmbH, Frankfurt am Main, pp 185-202

Korpi W, Palme J (1998) Paradox of redistribution and strategies of equality. Am Sociol Rev 63:661-687

Koudahl PD (2010) Vocational education and training: dual education and economic crisis. Procedia Soc Behav Sci 9:1900-1905

Mach A, Trampusch C (2011) The Swiss political economy in comparative perspective. In: Trampusch C, Mach A (eds) Switzerland in Europe. Routledge, London, pp 11-23

Mahoney J, Thelen K (eds) (2010) Explaining institutional change. Cambridge University Press, New York

Martin CJ (2017) Skill builders and the evolution of national vocational training systems. In: Buchanan J, Finegold D, Mayhew K, Warhurst C (eds) The Oxford handbook of skills and training. Oxford University Press, Oxford, pp 36-53

Martin CJ, Knudsen JS (2010) Scenes from a mall. Regul Gov 4:345-364

Martin CJ, Swank D (2008) The political origins of coordinated capitalism. Am Polit Sci Rev 102:181-198

Martin CJ, Swank D (2012) The political construction of business interests. Cambridge University Press, Cambridge

Mayer KU, Solga H (2008) Skill formation. Cambridge University Press, New York

Müller B, Schweri J (2012) Analyse zur Betriebszählung 2008 Die Betriebe in der dualen Berufsbildung. In: Statistik BF (ed) Statistik der Schweiz. Schweizerische Eidgenossenschaft, Neuchâtel

Nelson M (2012) Continued collectivism. In: Busemeyer MR, Trampusch C (eds) The political economy of collective skill formation. Oxford University Press, Oxford, pp 179-202

Peters BG (1998) Comparative politics: theory and method. Macmillan Press, London

Polito V (2014) Zehn Jahre Berufsbildungsgesetz, SGB Positionspapier. Schweizerische Gewerkschaftsbund, Bern

Ryan P (2012) Review of'The political economy of collective skill formation' and 'Switzerland in Europe'. J Vocat Educ Train 64:381-385

SBFI (2016) Evaluation EBA II Evaluation der Arbeitsmarktsituation und Weiterbildungsperspektive von Absolventen und Absolventinnen mit eidgenössischem Berufsattest. In: SBFI (ed) Zürich, LINK Institut

Schickler E (2001) Disjointed pluralism. Princeton University Press, Princeton

Schlumpf R (1999, March 19) Breite Unterstützung für den Lehrstellenbeschluss, Neue Zürcher Zeitung, Zürich, p 13

SDBB (2019) Eidgenössisches Berufsattest EBA. https://www.berufsberatung.ch/dyn/show/2101. Accessed 2 Apr 2019

Seitzl L, Emmenegger P (2019) How agents change institutions. Bus Polit 21:145-171

SERI (2017) Vocational and professional education and training in Switzerland facts and figures 2017. State Secretariat for Education, Research and Innovation, Bern

Stern S, von Dach A (2018) Evaluation der fachkundigen individuellen Begleitung (fiB) in zweijährigen beruflichen Grundbildungen mit EBA Schlussbericht. INFRAS. Staatssekretariat für Bildung, Forschung und Innovation SBFI in «Schriftenreihe SBFl»

Strahm RH (2008) Die entscheidenden Neunzigerjahre. In: Bauder T, Osterwalder F (eds) Jahre eidgenössisches Berufsbildungsgesetz. Hep verlag ag, Bern, pp 311-350

Streeck W (2009) Re-forming capitalism. Oxford University Press, Oxford

Streeck W, Thelen K (2005) Beyond continuity. Oxford University Press, New York

Theiss R (1996) Jugendarbeitslosigkeit in der Schweiz. PANORAMA 6:10-11

Thelen K (2004) How institutions evolve. Cambridge University Press, New York

Thelen K (2012) Varieties of capitalism. Annu Rev Polit Sci 15:137-159

Thelen K (2014) Varieties of liberalization and new politics of social solidarity. Cambridge University Press, Cambridge 
Thelen K, Busemeyer MR (2012) Institutional change in German vocational training. In: Busemeyer MR, Trampusch C (eds) The political economy of collective skill formation. Oxford University Press, Oxford, pp 68-100

Trampusch C (2010) Transformative and self-preserving change in the vocational education and training system in Switzerland. Comp Polit 41:187-206

Trampusch C, Palier B (2016) Between X and Y. New Polit Econ 21:437-454

WBK (1999) Lehrstellenbeschluss II. Kommission für Wirtschaft, Bildung und Kultur

\section{Publisher's Note}

Springer Nature remains neutral with regard to jurisdictional claims in published maps and institutional affiliations.

Submit your manuscript to a SpringerOpen ${ }^{\circ}$ journal and benefit from:

- Convenient online submission

- Rigorous peer review

- Open access: articles freely available online

- High visibility within the field

Retaining the copyright to your article

Submit your next manuscript at $\boldsymbol{\Delta}$ springeropen.com 